\title{
Wayfaring and Creative Practice in Tropical Far North Queensland Landscapes
}

\author{
Jacqueline Scotcher \\ Creative Arts, James Cook University, Australia
}

\begin{abstract}
Walking and the tropical Far North Queensland landscape of Australia have had a major influence on the author's creative research. In this paper, immersive practice, which includes walking, is examined as a means to form connections with the natural environment and stimulate imaginative thought. These attributes have developed the author's painting processes, which endeavour to enrich understandings of the landscapes of tropical far north Queensland. An immersive approach responds to the complexities of increasingly sedentary lifestyles and the tendency to engage with digital distractions in our high speed media-connected world. In this fast-paced realm, meaningful relationships with the natural environment can be reduced, with meandering and imaginative pursuits often becoming neglected. Living in Far North Queensland provides easy access to unique tropical landscapes to engage with. Walking receptively in such natural environments can provide a physical and mental counterpoint to contemporary fastpaced lifestyles. Furthermore, walking provides opportunities to engage in 'mindwandering' and embodied experience that can enrich painting practice.

The research presented in this paper celebrates life in tropical Far North Queensland and highlights the artist's experience in this particular part of the world. Recently, the $29^{\text {th }}$ of June was designated the International Day of the Tropics by the UN General Assembly, a day founded to raise awareness and consideration of both the challenges and opportunities faced by tropical regions of the world. (stateofthetropics.org). This designated day provides space for the author/artist to reflect upon the diverse culture and ecosystems of the region and position her artistic practice within a broader context of ideas relating to tropical environments.
\end{abstract}

Keywords: wayfaring, painting, immersive contemplative practice, tropical Australia

\section{Introduction}

This paper explores the significance of pedestrian movement in tropical Far North 1 Queensland (FNQ) Australia, and how these experiences are interpreted in the form of painting. Tropical environments of various regions of the world and/or walking have been 
identified as stimuli for creative pursuits for centuries, with Nietzsche, Wordsworth and Gauguin being notable advocates (Solnit, 2000; Wilson, 1998;). The unique tropical FNQ environment provides inspirational natural landscapes for artist-researchers such as myself to draw upon and interpret in paintings. Active research on foot in the region has enabled my artistic practice to develop, becoming more reflective of a receptive multisensory experience. Walking provides a slow-paced counterpoint to busy distraction-filled lifestyles and provides a period of calm for self-reflection. The works of art that have resulted from this bipedal approach differ from typical postcard 'rainforest to reef' representations that often dominate depictions of the tropical north Queensland region. This body of work reveals a unique vision and relationship between an artist and the FNQ tropical landscape, one that is informed by the receptivity afforded during walks in the natural environment.

The methodology informing this paper is practice-led research, in which this combination of theory, philosophy and practice allows myself as an artist-researcher to enrich and substantiate claims. In this paper, ideas of walking and its role in influencing creative practice will be outlined and help to situate my own creative work. This is followed by a review of immersive art practices in tropical regions and also temperate natural environments. Analysis of my own painting practice exploring the tropical FNQ environment in and around Cairns is then discussed in relation to its evolution since engaging with walking methods. The ideas expressed are part of continuing investigations.

\section{Current Lifestyles, Walking and Creativity}

A significant change in current lifestyles compared to those of the past is an overall reduction in bipedal movement. A troubling statistic is that in western cultures people are sitting an average of 9.3 hours per day, a practice Merchant (2016) describes as the smoking of our generation'. In addition, neuroscientist Daniel Levitin (2015) explains that we live in an age of 'information overload', where we absorb twenty-five times more information daily than we did twenty-five years ago. This combination of increasingly sedentary and distraction-filled lifestyles may differ in impact between individuals but overall it has been identified as a worrying lifestyle trend. As a result, pedestrian movement that often includes interactions with nature can become limited, and essential neurological resources that we require to think deeply may diminish (Levitin, 2014).

Responding to a contemporary concern is an agenda of contemporary arts practice (Evans, 2012). Terry Smith (2011) is an international authority in art theory and identifies the exploration of contemporary/personal concerns as a core current in contemporary art. Artists investigate "concerns they feel personally yet share with others, particularly of their generation... responding to life now and what shapes time, place, media and mood" (Smith, 2011, p. 10). Considering how contemporary pressures affect one's sense of selfhood, and acting with perceptive awareness to improve situations, underpins much of contemporary art (Smith, 2011). 
In my artistic practice/research walking is employed as a counterpoint method to the personal concern of increasing information overloaded, sedentary lifestyles and the disconnection with the natural environment that may result. Walking is used as a way to connect in a direct physical manner with the natural tropical landscape of Cairns and surrounding regions. Through bipedal explorations of the landscape and reinterpretations through painting, personal connections with the natural landscape are investigated and can be shared with others. Art theorist Gordon Graham (1997) presents that works of art have the capacity to invite new understandings on a given subject through sensuous means. The intent for these artworks is to reveal the immersive experience of walking in the tropical landscape and the significance of human/nature relationships through sensuous paintings.

Several theorists identify the benefits of pedestrian movement and these attributes help to explain why walking works as an effective research method for creative practice. Rebecca Solnit (2000) writes that "exploring the world is one of the best ways of exploring the mind, and walking travels both terrains" (p. 13). This idea suggests that the slower physical pace of pedestrianism allows time for contemplation and affords a mediative disposition. Walking produces a more centred and reflective state of being (Edensor, 2000), or as Frederic Gros (2015) describes, a walking pace allows for the mind to 'catch up' and the meaningful to be separated from the trivial.

This clarity of thought may provide a more acute sensitivity to surrounding environments. A mindful or receptive walker becomes aware of the 'bodily performances' undertaken when walking that include 'observing, monitoring, remembering, listening and touching' and they embrace this embodied experience (Ingold \& Vergunst, 2008, p. 5). Jung (2014) suggests that receptive pedestrian interactions shape a more holistic experience of place and provide an important way to understand and connect with the world around us. Being present whilst walking not only develops understandings of the physical terrain, climate, flora and fauna but also provides a pathway to deeper knowledge of self (Ingold, 2007). Robert Macfarlane (2012) expresses the same idea: "I have long being fascinated by how people understand themselves using landscape, by the topographies of self we carry within us and by the maps we make with which to navigate these interior terrains" (p. 26). Walking provides a slow-paced and personalised pathway into these internal landscapes.

Historical figures make note of the influence of walking in relation to their creative and philosophical practices. Nietzsche (2013/1889) wrote that 'all truly great thoughts are conceived by walking' (p. 34). This notion is supported by Rousseau's walking activity, as he consistently retreated to forest paths to think and enhance philosophical thought (Solnit, 2000). He also used walking to escape the social pressures of the time and this Sixteenth century strategy still has uncanny relevance today, albeit now we may escape the social pressures of social media and digital distractions (Gros, 2015).

Another prevalent walker was Romantic poet William Wordsworth, he described how the 'pedestrian viewpoint' afforded a perceptive awareness and pace that allowed his gaze to linger, for wonder and beauty to be highlighted even on routes he repeatedly travelled (Gaillet- 
De Chezelles, 2010). For Wordsworth, wandering was an essential part of life that provided his poetry with enduring images of specific features rather than generalisations and also with a unique walk-like rhythm (Solnit, 2000). Contemporary writers consolidate these historical ideas in describing "walking in a straight line, prevents us from thinking in straight lines" (Morrison-Bell, Collier, Ingold \& Robinson, 2013). The simple, largely unchanged practice of pedestrianism continues to remain a valid strategy in philosophical and creative pursuits.

Anecdotal accounts of pedestrian movement producing creative insights have been confirmed more recently through empirical research. Marily Oppezzo and Daniel Schwartz (2014), for instance, conducted a study concluding that people were more creative when walking in comparison to being seated, particularly in outdoor spaces, and notably the walking had a residual affect afterwards. In one experiment of forty adults, $100 \%$ of participants were more creative when walking, they could think of more quality divergent responses to given situations compared to their own creative standard (Oppezzo \& Schwartz, 2014). This seems to indicate that as we undertake the almost unconscious activity of placing one foot in front of the other, the imagination and higher faculties gain the mental space to meander (Morrison-Bell et al., 2013).

Importantly Oppezzo and Schwartz's (2014) study revealed that walking in natural environments had the most positive effect on developing imaginative insights. Macfarlane (2012), who is a highly experienced walker, observes that interactions with nature reveal or unfold moments and insights in a discreet and sometimes wondrous manner. By contrast, urban environments can be over stimulating and capture our attention dramatically, such as by a car horn. This makes them less restorative as well as interruptive to natural walking and thinking rhythms (Berman, Jonides \& Kaplan, 2008). This notion is particularly important when considering the local FNQ tropical landscape in and around the city of Cairns. For here the natural environment is ever present and there are pockets of seemingly untouched natural landscape readily available for exploration.

Several contemporary artists have used walking to connect and recognise the natural environment. British artists Richard Long and Hamish Fulton are globally recognised as 'walking artists' and embody many of the ideas that historical walkers have expressed (Solnit, 2000). These artists mainly explore temperate climates in their works of art. The outcomes are very different to my own walking art practice, however reviewing their practices helps to situate my own in a broader context and allows for a point of comparison to the unique experiences offered through a tropical environment. 


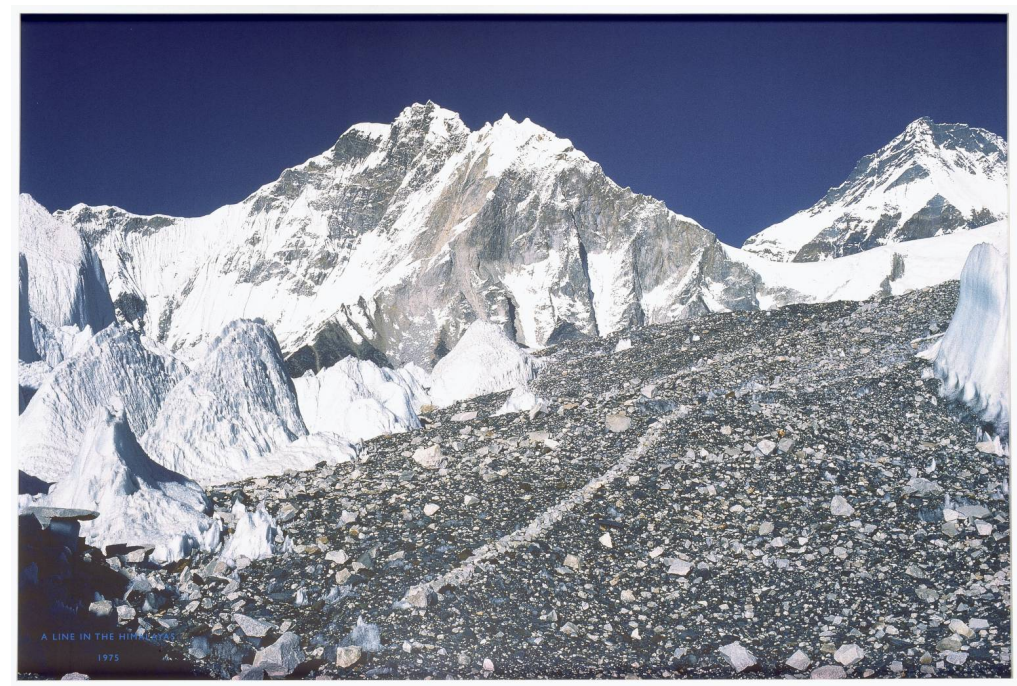

Figure 1. Richard Long, A Line in the Himalayas, 1975 printed 2004, digital print on paper mounted onto aluminium, $86 \times 128 \mathrm{~cm}$

For Long, walking became the framework for his practice, whereby his body acts as a unit of measure to explore and reinterpret the natural environment (Braziller, 1991). As much as the body is a point of measure, footfall became a way of seeing, thinking and knowing the landscape (MacFarlane, 2012). Long's website summarises his practice as "simple creative acts of walking and marking about place, locality, time, distance and measurement" (richardlong.org).

The artwork in Figure 1 shows that the artist has an invisible presence in the artwork. Natural materials are rearranged and become an ephemeral sculptural form within the landscape. The viewer's imagination is ignited through the empty physical traces produced by Long; they become engaged in an inner journey, even if it is a differing path to the artist (Braziller, 1991). As Solnit (2000) argues, this reliance on ambiguous presence is an underpinning feature in much contemporary art, where the viewer has to engage, imagine and fill in the purposely-left gaps in order to make sense of the artwork.

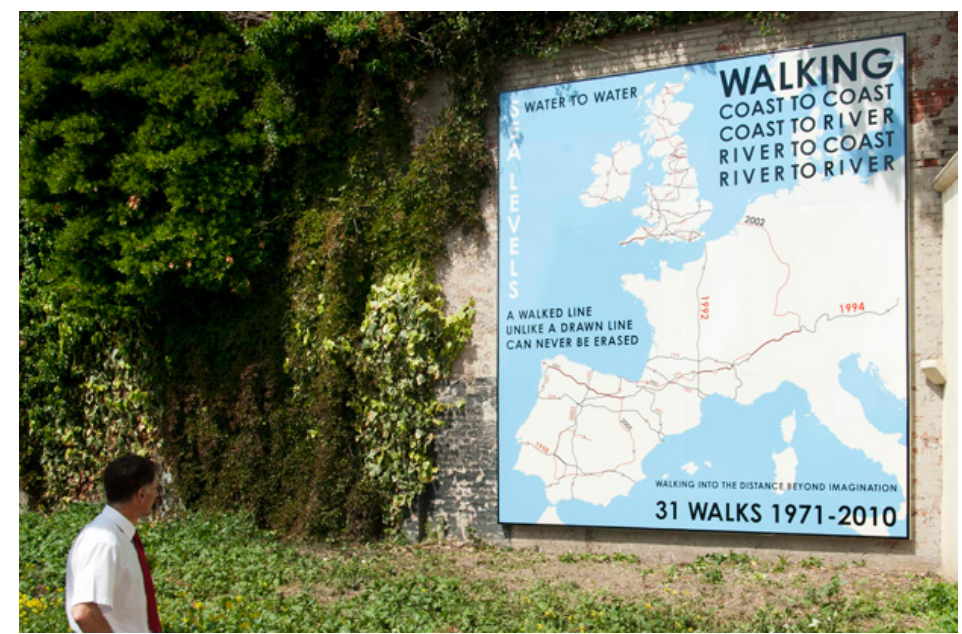

Figure 2. Hamish Fulton, 31 Walks from Water to Water, 1971-2010, Made on Western Europe, 2011, metal sign, dimensions unknown 
A deep respect for nature is also embodied in Fulton's creative practice (Tate, 2016). Walking is employed as an art form in its own right; his practice does not require materials or a studio and his motto is 'no walk, no work' (Fulton, 2010).

Walking must be slow and contemplative for the artist (Fulton, 2010). He is another walker who claims that the slow pace provides a contrast to the present societal priority of speed and convenience and develops relationships with the natural environment (Schlieker, 2011). Fulton (2010) writes that "our rejection of nature is the cause of global warming, walking allows us to be influenced by nature and gain an attitude of respect for all life-forms not just human life" (p. 9). To pay homage to the natural environment Fulton employs natural barriers to determine his walks rather than man-made (“Folketone Artworks", 2013). The Figure 2 image shows the mapping of walks undertaken across the British Isles and Western Europe during his forty-year career, with coasts or rivers as boundaries ("Folkestone Artworks", 2013). The sign records the walks, but the actual artwork is the walk itself.

The longevity of both Fulton and Long's practice reveals that there are always new ways to explore walking. As walking in natural environments develops deeper connections to the surrounding landscape, the resulting artworks provide new arenas of contemplation for the viewer (Morrison-Bell, 2013). These practitioners invite the viewer to reconsider the landscape and their interactions with it and this is an approach I have applied to the tropical FNQ landscape.

\section{Natural Landscape and Immersive Artistic Practice}

Locality and place play an important influential role for artists, providing visual materials and stimuli (Drake, 2003; Baker, 1991). The influence of temperate natural environments is clearly evident in the previous example of Long and Fulton's practices. Tropical environments in particular can have a major influence on creative practitioners. For instance, Susan Luckman's (2009) research indicates that creative practitioners in Darwin rate the surrounding natural environment as a dominant influential aspect to their original work. This is in contrast to city dwellers living outside of the tropics who claim networking advantages of urban locations as paramount. Natural landscapes that are prevalent in tropical areas provide mental 'space' or 'retreat' required for creativity, a quality Luckman (2009) highlights is lacking for artists in cities. I have found that through combining the 'space' of the natural FNQ landscape with the pace of walking that a clear headspace and deeper connection to my surrounds is cultivated.

The lure and significance of tropical environments to artists is not a novel concept. It was over a century ago that Gauguin famously retreated from European civilisation to the South Pacific in search of new exotic sources of inspiration (Gompertz, 2012). In addition, the proclaimed art historian Bernard Smith (2002) notes that artists unavoidably bring their own aesthetic vision to exotic tropical landscapes, as the environment affects objective description. The exhibition Escape Artists: Modernists in the Tropics curated by Gavin Wilson (1998) demonstrates that the FNQ landscape has attracted many artists. The exhibited works of art 
explore "the immense diversity of the natural world of the tropics" and reveal that artists have the capacity to capture the texture, feel, colour and atmosphere of a place (Wilson, 1998, p.9).

Works of art, such as those in Escape Artists, provide a differing perspective to the stereotype postcard image of the region. Sasha Grishin (2013) describes valuable Australian landscape artists as re-inventors of the landscape who explore the spiritual and physical, rather than produce a mimetic rendition. This suggests that capturing the essence of a landscape/environment can be important for artists. Or in relation to walking in the landscape, the journey is as significant as the destination or vista reached. From a phenomenological perspective, Merleau-Ponty theorizes that : 'the painter "takes his body with him"... indeed we cannot imagine how a mind could paint. It is by lending his body to the world that the artist changes the world into paintings' (Merleau-Ponty, 1993, p. 123). A physical connection to the landscape can help an artist tap into the spirit of a landscape and reinvent it originally through creative practice.

In order to understand the environment more deeply many artists employ an immersive approach to their surroundings, such as that demonstrated by walking artists Long and Fulton. Artist Kandinsky distils this practice in writing: "one can look at it as if through a pane, or one can plunge into it, become an active part of it and experience its pulsation with all our senses" (cited in Ingold, 2010, p. 21). A worthy example of 'plunging into' the landscape is portrayed in the Figure 3 image, where acclaimed contemporary Australian landscape artist John Wolseley is pictured. Here he emerges from a creek bed and uses ink, the earth, and true to his endearing eccentric form, a dead pelican, to produce visual studies. During a chance personal meeting with the artist, Wolseley suggested that a way to comprehend the essence of the landscape was to take your shoes off and squelch in the mud or feel the dry dust underfoot. Although, due to crocodiles, this submersion may not be appropriate in FNQ, Wolseley's practice in the broader Australian landscape demonstrates how immersive techniques work towards an embodiment of a true sense of being in the environment.

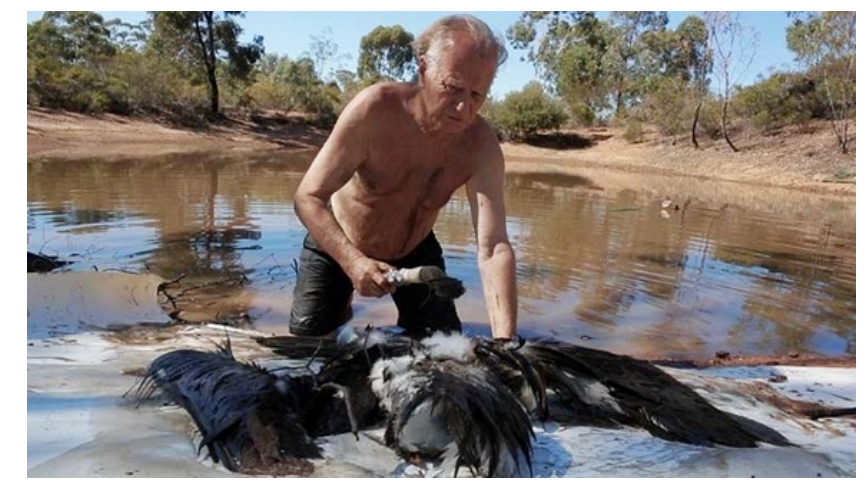

Figure 3. John Wolseley at work, a film still from a National Gallery of Victoria documentary showing artist John Wolseley, 2015

Immersive creative practice is appealing as it provides opportunity for layers of multi-sensory experience to be explored and re-interpreted through materials. The images referenced in this paper show that immersive creative practice often results in abstraction or imaginative reinterpretations. James Baker (1991) comments on this notion: 
Freedom from the literal not only permits emphasis on some feature of the environment, or the omission of elements that are not relevant to the idea in the work. It leads on to abstraction, so that the artist can explore the responses to colour, form, texture and arrangement without any duty or reference to a specific object. Abstraction born of the landscape carries with it the same messages and can be a vital element in taking art from the landscape that next step into the landscape of the mind (p. 4).

By moving beyond literal representation into abstraction a work of art may embody both the interior and exterior terrains experienced by the artist, thus revealing new insights.

There is historical precedent that connects immersive artistic practice with capturing the spirit of natural environments. Through his works, the Modern master Cezanne shifted how the landscape was represented in painting. He observed that "we no longer see nature; we see pictures over and over again" (cited in Andrews, 1999, p. 177). Cezanne was not in the business of capturing a 'picture-perfect' representation, but rather a new perspective towards the landscape (Gompertz, 2012). Another poignant historical example would be J.M.W Turner, who famously used immersive practices by being strapped to the mast of a ship during a storm as research for a painting (Figure 4). The painting was ridiculed at the time, however Turner did not mind if the work was 'liked', his aim was to capture what it felt like being amongst the elements (Andrews, 1999).

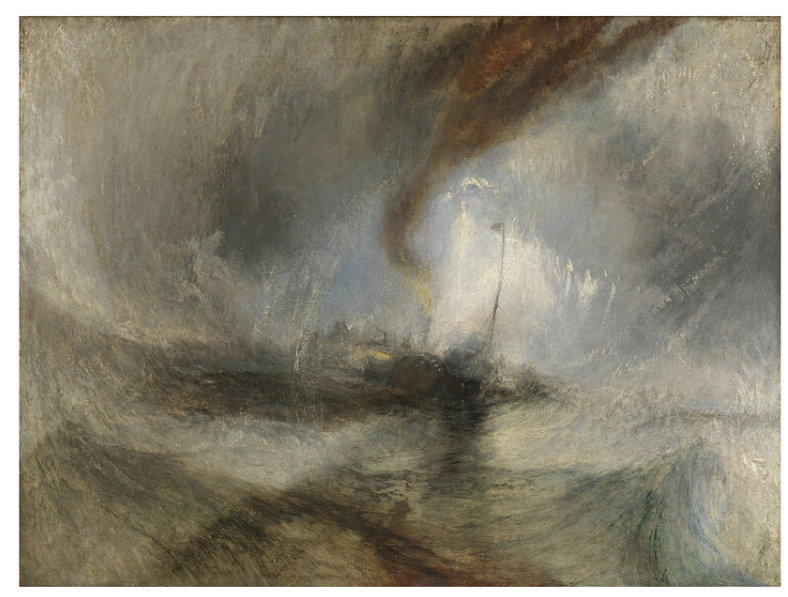

Figure 4. J.M.W. Turner, Snow Storm- Steamboat off a Harbour's Mouth making Signals in Shallow Water, and going by the Lead. The Author was in this Storm on the night Ariel left Harwich, 1842 , oil on canvas, $91.4 \times 121.9 \mathrm{~cm}$

The tropical FNQ environment has also being investigated through embodied experience to produce unique interpretations of the landscape. John Firth-Smith is an artist who has explored the Far North and produced paintings that capture more than the visual experiences. Techniques of close observation, consistent travel and the reworking of paint surfaces combine to produce depth and emotion within his paintings (Grishin, 2013; Wilson, 1998).

Through (Figure 5) is textural and raw, making abstract reference to an islander's hut he may have encountered (Wilson, 1998). The contrast between light and shade and gritty palette 
reflects a broader feeling and texture of the place explored rather than an imitative depiction. Firth-Smith expresses how a painting "is not always the thing that's happening in the distance, it's the thing that's happening above you and below you and inside you as well" (cited in Wilson, 1998, p. 117). This quote shows that Firth-Smith, much like Turner, did not present a single point view of the FNQ landscape, but rather included how it made him feel and how it embodied a psychological space (Grishin, 2013).

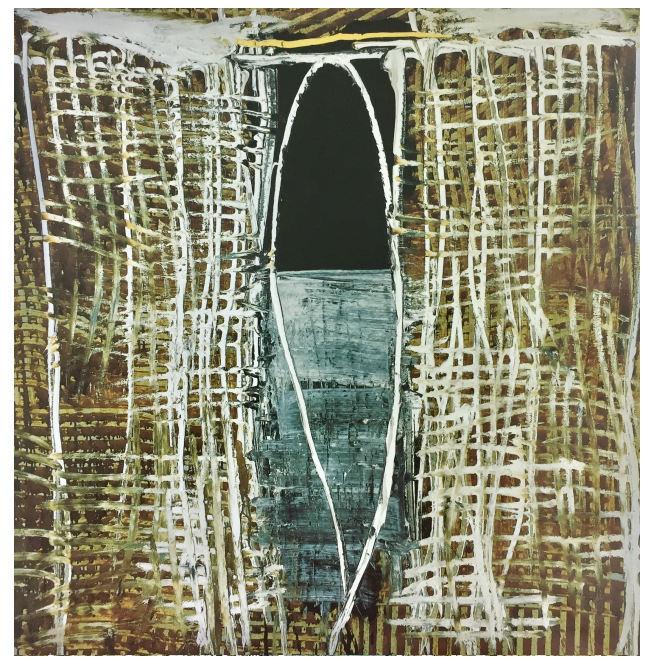

Figure 5. John Firth-Smith, Through, 1988, oil on linen 122 x $122 \mathrm{~cm}$

Painter Yvonne Cohen also spent time in FNQ, relocating in the 1930s from Melbourne to the fairly isolated Dunk Island south of Cairns (Wilson, 1998). Cohen too could be considered to have employed immersive practices due to her commitment in living on Dunk Island. The island provided idyllic scenery to draw from but also challenges to living, as supplies were often limited and the tropical climate full of extremes (Wilson, 1998). Due to its location, there was no simple escape back to 'civilisation' from the island, and immersion was somewhat compulsory.

In contrast to Firth-Smith's earthier colour palette, Cohen captures her experience of the tropical FNQ landscape through a much brighter palette. This colour presents a different interpretation and atmosphere towards the FNQ landscape, reminiscent of other tropical painters such as Gauguin. Mango Trees pictured in Figure 6 shows a vibrant scene with purple palm trunks and red mountains. The landscape has movement, bright warm tones and dark shadows. The heightened colour and lively brushwork is understandable considering the contrasting terrains Cohen encountered between the new tropical landscape and that of her previous Victorian home. 


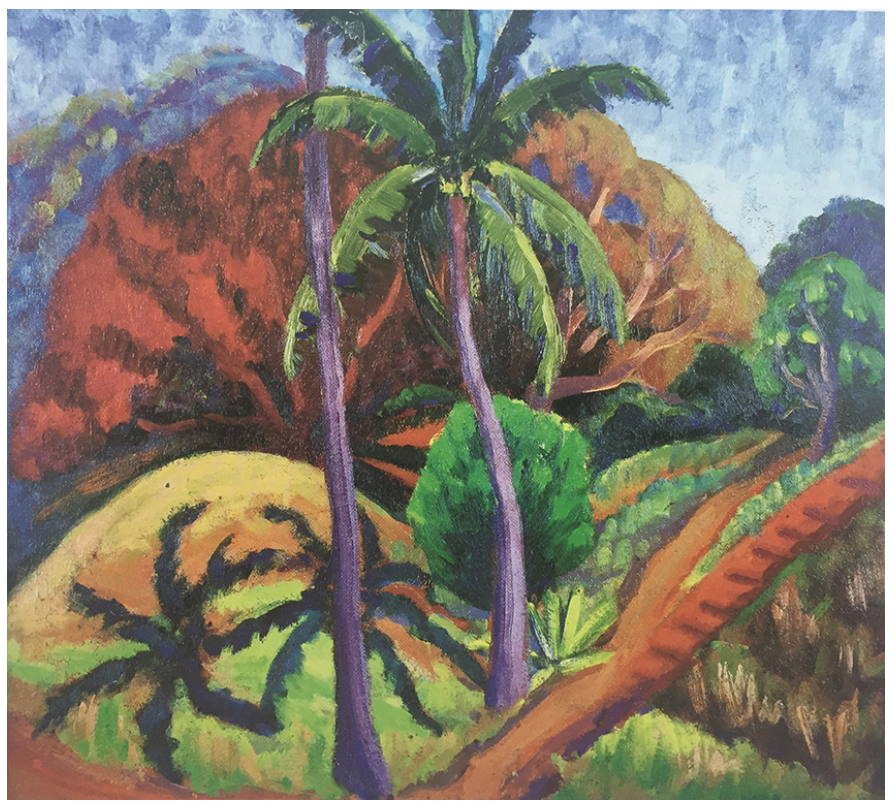

Figure 6. Yvonne Cohen, Mango trees, 1945, oil on composition board, $45.5 \times 50.5 \mathrm{~cm}$

The tropical landscape of FNQ seems to lend itself to immersive artistic practice; perhaps this is due to the abundance and diversity of the natural environment. Artists who explore the region apply their own unique perspective to the environment and produce differing responses that all contribute to diverse understandings of place.

\section{Author's Works: Slowing physical pace in Tropical FNQ}

The natural tropical landscape has been the focus of my painting practice since relocating to FNQ five years ago. I have explored the local region through creative practice in order to understand the surrounding environment, develop a sense of place and convey this understanding to others. However, my practice has developed significantly since walking has become a foundational research method. Receptive walking has been employed as a method at a variety of sites and overall it affords a richer connection to the tropical landscape which informs creative practice.

Walking has provided a means to become more observant. The slow bipedal pace allows for details to be noticed that would be missed if I were driving. However, walking in FNQ differs greatly to say the Romantics who may have meandered through the countryside. The tropical landscape requires more structured wayfaring.

The landscape can be rugged with hill climbs, rock hops and the constant challenge of uncertain surfaces. There is also the dual seasonal climate to consider, tropical humidity, and the sometimes-dangerous flora and fauna such as the stinging tree, cassowaries, crocodiles and a plethora of bugs and 'bitey' things. Being prepared, following designated paths, obtaining maps and adhering to the arrowhead markers are part of the local walking ritual. The experience may be hot, gritty and require some caution, but walking in the FNQ landscape is simultaneously rewarding. Vast vistas, exquisite plant life, waterfalls and new unexpected 
sights are among the extreme highlights of the region. All these aspects, both the challenging and beautiful, contribute to the painterly expression.

To use Wordsworth's term, the 'pedestrian perspective' and embodied experience has deepened my understanding and appreciation of the tropics. I have long being interested in movement and the landscape as a basis for creative practice and prior to walking I would take long drives throughout the region. This process provided a broader overview of the landscape, including its colour, changing seasons and industry. However, I agree with Edensor (2000) who suggests that other modes of travel to pedestrianism, such as by car or train, do not afford such direct experience and sensual understandings of the landscape. In a car we may indeed move across the landscape at speed and observe much, but Ingold (2007) argues that during such travel we become a 'strapped-in' passenger rather than an active participant. This is poignant in FNQ as the air-conditioned comfort of a car detaches oneself from the distinctive humidity and temperature of the place.

Drivelines (Figure 7) is an earlier painting responding to drives between Cairns and Port Douglas. It exhibits lines that express fleeting movement. These gestures were derived from line drawings made by holding pen to paper throughout the winding road travel. Although the colour palette and marks are expressive of the driving experience, upon reflection I have found that a connection between the landscape and myself was lacking, the 'spirit' of place was not successfully embodied in the work.

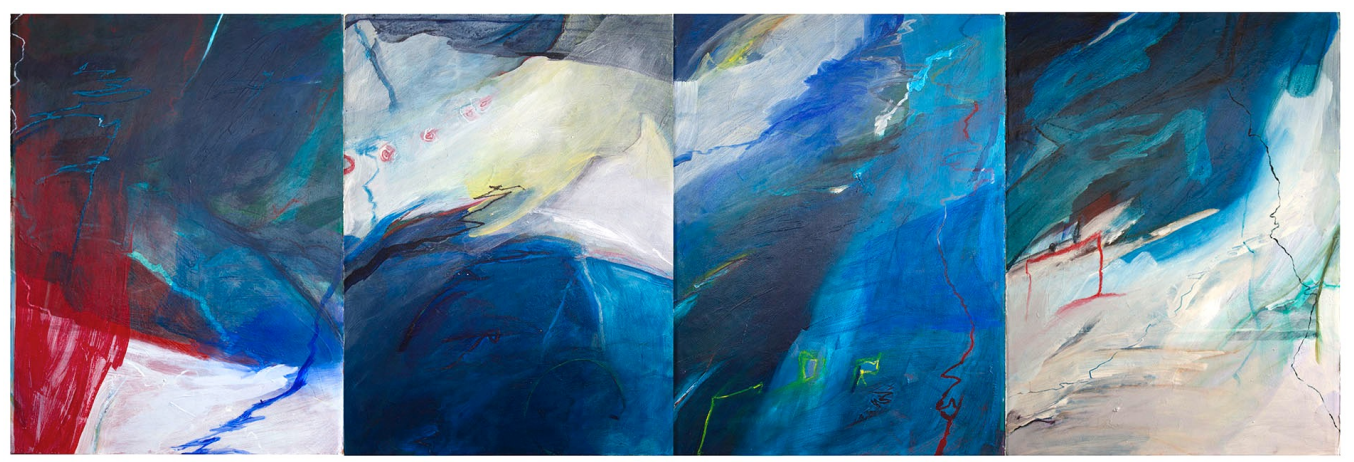

Figure 7. Jacqueline Scotcher, Drivelines, 2012, synthetic polymers \& ink on paper, 220 x 77cm 


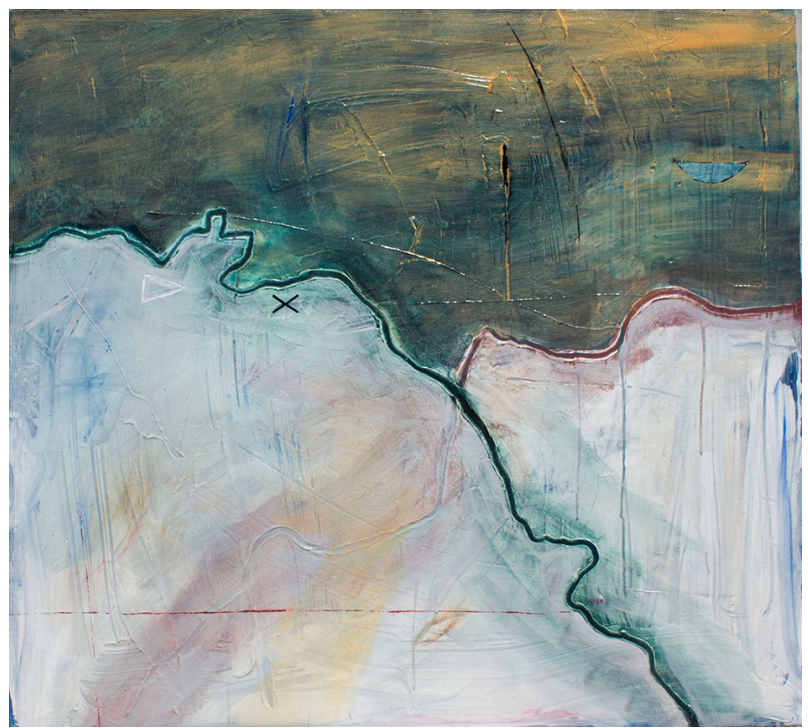

Figure 8. Jacqueline Scotcher, Wayfaring II, 2015, Synthetic polymers on canvas, $110 \times 100 \mathrm{~cm}$

Wayfaring II (Figure 8) shows a later painting reinterpreting local terrain using walking methods. Here the surface is far more textured and layered, perhaps not as superficial as the surface of Drivelines. Specific painting processes are chosen to reflect the actions undertaken on foot including, forging a slower line through the composition by the removal of material, much like when walking on a bush track. The line meanders across the surface pushing paint upwards to each side. These lines could become representative of paths of movement, a mapped aerial view, jumbled hill lines or a river that was crossed. Visual compositional elements are employed to produce movement and direction, aiming to provoke the viewer's imagination so they move through the composition as one would move through the landscape.

The physical pace and experience of the landscape was re-enacted during the studio painting process of both of these artworks (Figures $7 \& 8$ ). While driving provided speed and abundant visual stimulus to draw from, walking research allowed for more complex embodied experiences to inform the painting. The rhythm of walking readily invites individualised interactions such as meandering off course, pausing for closer observations and opportunities to feel, smell and taste the materials that constitute the landscape being moved through (Edensor, 2000). This personalised time and experience do not invite the same prominence in other travel modes.

Philosopher Edward Casey (2005) describes the creative process of retracing bodily movement through the landscape as 'body-mapping'. Casey (2005) argues that:

The artist's body, as a whole moving mass, displays the sense of place it paints, first in its gesticulations and then in the ensuing painted image. The gesticulations already incorporate into the body a sense of the circumambient landscape. Just as this landscape is retraced in bodily motions, so these same motions leave traces on the canvas that, rather than representing the landscape's precise contour, reimplace them on the pictorial surface' (p. 261). 
I discovered that pedestrian movement innately facilitates body-mapping as the landscape, walking body and painting process, become deeply interconnected and reflective of each other. Walking provides a deep-seated experience that can be drawn from whilst painting and this idea also links to Merleau-Ponty's (1993) phenomenological notion that a painter 'lends his body to the world'. Body-mapping the landscape through painting can also encompass the imaginative aspect of mind-wandering which bipedal movement encourages.

The influence of walking and the tropical FNQ landscape was amplified during a four-day hike on Hinchinbrook Island. Hinchinbrook Island lies off the coast of North Queensland, $200 \mathrm{~km}$ south of Cairns and is one of Australia's largest national parks (http://www.nprsr.qld.gov.au/). The concentrated time on the island with no phone or Internet access, the surrounding wild environment and punctuated steps from the pack weight, meant that the unique attributes of the tropics were heightened. Included in the trek were several creek crossings, as well as journeys through rainforest, eucalypt forest, mangrove and paperbark country. A true scope of the tropical landscape was encountered and a deeper respect for the environment was gained during this time.
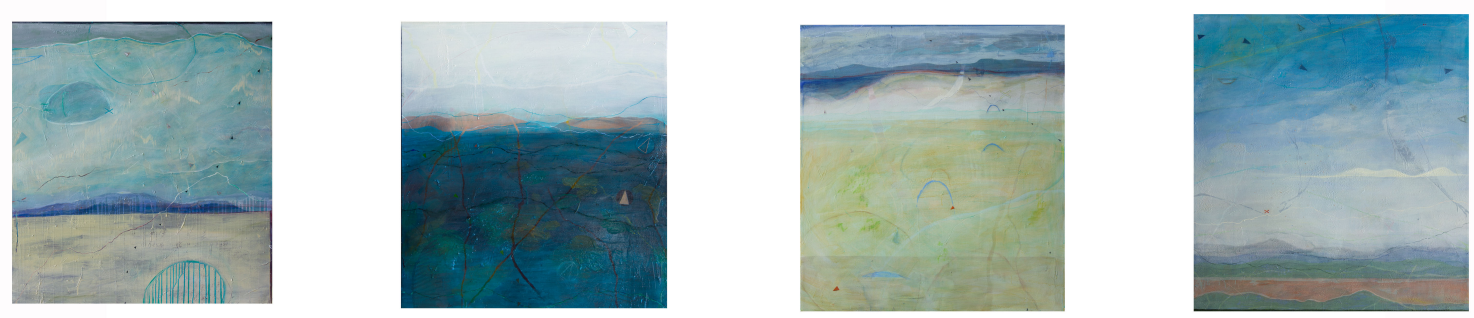

Figure 9. Jacqueline Scotcher, Hinchinbrook Island Walk No.1-4, 2016 Synthetic polymers on canvas, each $110 \times 120 \mathrm{~cm}$

Four paintings were produced in response to the four-day walk. The Hinchinbrook Island Walk paintings (Figure 9) are individual compositions, yet they play together through the use of line, colour and direction. Minimal and small 'man-made' symbols are chosen to emphasise the dominance of the natural terrain and how small I felt during the walk in comparison to the epic tropical landscape. The painting in Figure 10 employs dripping paint to re-imagine the pouring tropical rain experienced and pool-like shapes to represent the natural swimming holes that served as well-needed places to bathe and relax. Repetitive dash-like marks are incorporated to simulate footsteps, forming floating hill shapes. Across the four paintings a body-mapped feeling of the undulating terrain is conveyed through shifting horizon lines and directional properties. 


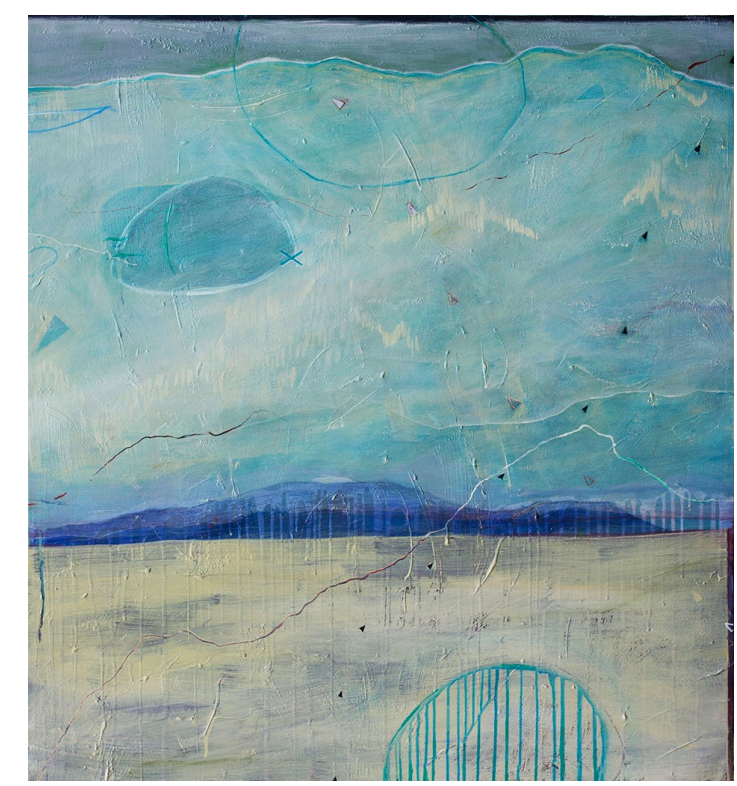

Figure 10. Jacqueline Scotcher, Hinchinbrook Island Walk No.1, 2016 Synthetic polymers on canvas, $110 \times 120 \mathrm{~cm}$

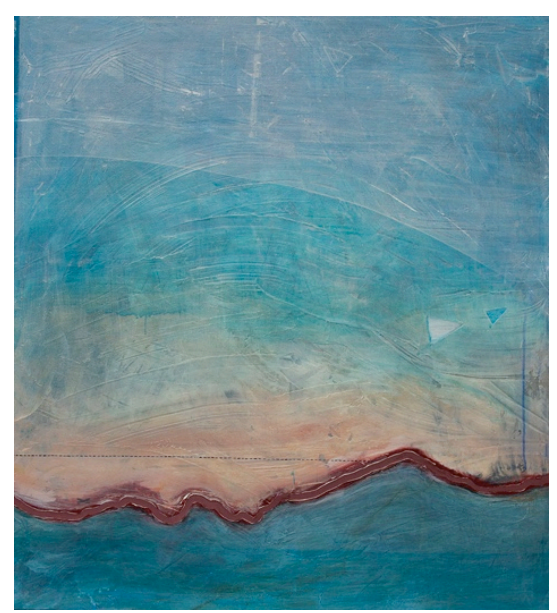

Figure 11. Jacqueline Scotcher, Headspace, 2015, Synthetic polymers on canvas, $100 \times 110 \mathrm{~cm}$

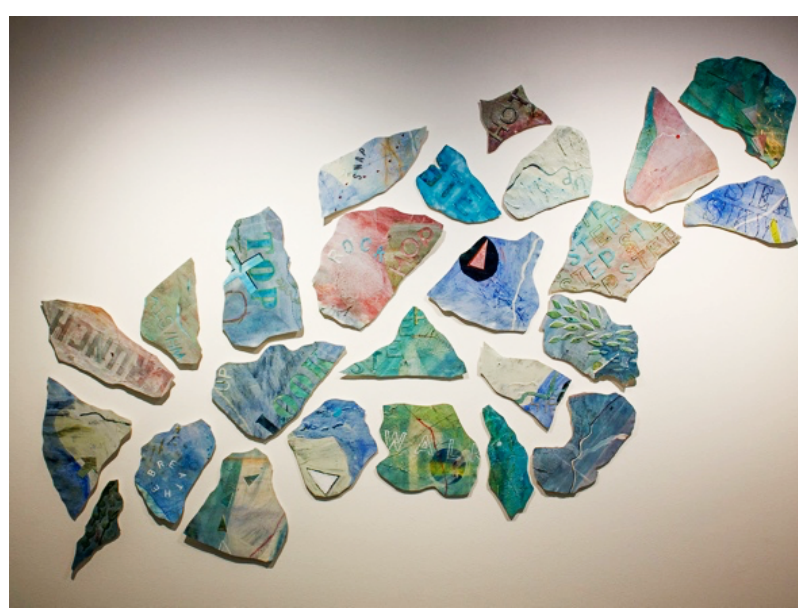

Figure 12. Jacqueline Scotcher, Rock Hop, 2015, synthetic polymers on canvas, sizes variable

The sustained walking experience of Hinchinbrook Island was a memorable research experience. However, the everyday rituals of walking on the beach or through local bush tracks have layered to become a significant part of building understandings of place and informing artistic practice. Headspace (Figure 11) is a painting that references regular local beach walks at dawn or dusk and how the natural beauty combined with the slow pace affords clarity of thought. Rock Hop (Figure 12) is a playful response to creek crossings common on walking trails, the integration of onomatopoeia into the art practice is used to imply a multisensory experience. All of the works of art developed out of walking practices have a textural, layered surface, and a more refined colour palette intending to be more reflective of the FNQ region. 


\section{Conclusion}

Walking has been a successful research method in the development of my creative practice which explores the FNQ landscape. The tropical environment is inherently captivating for many artists, but engaging with the immersive act of receptive walking has afforded a deeper connection with the natural environment that can enrich my own painterly reinterpretations.

Philosophers have historically acknowledged the benefit of pedestrian movement in natural environments to stimulate contemplative thought, while contemporary walking artists and those with immersive practices continue to exhibit the significance of direct bodily experience in creative practice. The artistic body of work produced during this research is not only exploring the physical natural landscape but readily meanders into mental terrains and spiritual places that the physical incites. The creative output of this research reveals an alternate perspective of the local tropical environment that hopefully will deepen understandings of its unique qualities and the significance it plays in our lives.

The International Day of the Tropics provides such a forum for specific and diverse aspects of tropical regions to be considered and discussed, in multiple voices and through various medium. Forty percent of the world's population currently dwell in Tropical regions (stateofthetropics.org), so deeper understandings of life in tropical environments, including the changes and challenges faced by its people's and societies as well as natural environments, affect many. As an artist I aim to add to the broader conversations that the International Day of the Tropics facilitates by highlighting the specific terrain of the local far North Queensland area and expressing the significance of my personal relationship with it through painting artefacts. Possibly, by reflecting upon artwork, or taking the time through slow-paced walking, we may observe and understand the surrounding tropical landscape more intimately and respectfully.

\section{References}

Andrews, M. (1999). Landscape and western art. Oxford, United Kingdom: Oxford University Press.

Baker, J. (1991). From the landscape: A review of the influence of the landscape in contemporary art. Brisbane, Australia: The Museum of Contemporary Art.

Berman, M., Jonides, J., \& Kaplan, S. (2008). The cognitive benefits of interacting with nature. Psychological Science, 19(12), 1207-1212. doi: 10.1111/j.1467-9280.2008.02225.x

Braziller, G. (Ed.). (1991). Richard Long: Walking in circles. New York, NY: George Braziller.

Casey, E. (2005). Earth-mapping: artists reshaping landscape (Vol. N - New). Minneapolis, MN: University of Minnesota Press.

Drake, G. (2003). 'This place gives me space': Place and creativity in the creative industries. Geoforum, 34(4), 511-524. doi: 10.1016/S0016-7185(03)00029-0

Edensor, T. (2000). Walking in the British countryside: Reflexivity, embodied practices and ways to escape. Body \& Society, 6, 81-106.

Evans, D. (Ed.). (2012). The art of walking: A field guide. London, United Kingdom: Black Dog Publishing.

Folkestone Artworks. (2013). 31 Walks from water to water 1971 - 2010 Hamish Fulton. Retrieved from: http://www.folkestoneartworks.co.uk/artists/hamish-fulton/ 
Fulton, H. (2010). Walk. Visual Studies, 25(1), 80-14. doi:10.1080/14725861003606696

Gaillet-de Chezelles, F. (2010). Wordsworth, a wandering poet: Walking and poetic creation. Études Anglaises, 63(1), 18-33.

Gompertz, W. (2012). What are you looking at? 150 Years of modern art in the blink of an eye. London, United Kingdom: Viking.

Graham, G. (1997). Philosophy of the arts: An introduction to aesthetics. Abingdon, United Kingdom: Routledge.

Grishin, S. (2013). Australian art: A history. Carlton, Australia: The Miegunyah Press.

Gros, F. (2015). A philosophy of walking. London, United Kingdom: Verso.

Ingold, T. (2007). Lines: A brief history. London, United Kingdom: Routledge.

Ingold, T. (2010). Ways of mind-walking: reading, writing, painting. Visual Studies, 25, 15-23. doi:10.1080/14725861003606712.

Ingold, T. \& Vergunst, J.L, (Eds.). (2008) Ways of walking: Ethnography and practice on foot. London, United Kingdom: Ashgate Publishing

Jung, Y. (2014). Mindful walking: The serendipitous journey of community-based ethnography. Qualitative Inquiry, 20, 621-627. doi: 10.1177/1077800413505543.

Levitin, D. (2014). The organized mind: Thinking straight in the age of information overload. London, United Kingdom: Penguin Books.

Levitin, D. (Guest Presenter). (2015, September 5). All in the Mind ABC Radio [Audio podcast]. Retreived from http://www.abc.net.au/radionational/programs/allinthemind/dr-daniel-j.levitin/6744490

Luckman, S. (2009). Creativity, the environment and the future of creative lifestyles: Lessons from a creative tropical city. The International Journal of Humanities, 7(6), 1-10.

Macfarlane, R. (2012). The old ways: A journey on foot. London, United Kingdom: Hamish Hamilton.

Merchant, N. (2016). Got a meeting? Take a walk [Video of presentation]. Retrieved from TED: https://www.ted.com/talks/nilofer_merchant_got_a_meeting_take_a_walk/transcript?language

Merleau-Ponty, M., Johnson, G. \& Smith, M. (1993). The Merleau-Ponty aesthetics reader: Philosophy and painting. Evanston, IL: The Northwestern University Press.

Morrison-Bell, C., Collier, M., Ingold, T., \& Robinson, A. (2013). Walk on. Manchester, United Kingdom: Cornerhouse Publications.

Nietzsche, F. (2013). Twilight of the idols, or how to philosophize with a hammer (D. Fidel Ferrer, Trans.). Leipzig, Germany: Verlag von C. G. Naumann. (Original work published 1889)

Oppezzo, M. \& Schwartz, D. (2014). Give your ideas some legs: The positive effect of walking on creative thinking. Journal of Experimental Psychology, 4O(4), 1142-1152. doi: $0.1037 / \mathrm{a} 0036577$

Schlieker, A. (2011). Folkestone triennial: A million miles from home. United Kingdom: Cultureshock Media.

Smith, B. (2002). A pavane for another time. South Yarra, Australia: Macmillan Art Publishing.

Smith, T. (2011). Contemporary art world currents. London, United Kingdom: Laurence King Publishing.

Solnit, R. (2000). Wanderlust: A history of walking. London, United Kingdom: Penguin Group.

Tate, (2016). Hamish Fulton: Walking journey. Retrieved from: http://www.tate.org.uk/whats-on/tatebritain/exhibition/hamish-fulton-walking-journey

Wilson, G. (1998). Escape artists: Modernists in the tropics. Cairns, Australia: Cairns Regional Gallery.

\section{List of Figures}

Figure 1. Richard Long (1975, printed 2004). A line in the Himalayas [Digital print on paper mounted onto aluminium]. Tate Collection. Retrieved on 30 November 2016 from: http://www.tate.org.uk/art/artworks/long-a-line-in-the-himalayas-t12035 
Figure 2. Hamish Fulton (1971-2010). 31 Walks from water to water, made in Western Europe, 2011, [Metal sign], Folkestone Triennial. Retrieved on 1 December 2016 from: http://www.folkestoneartworks.co.uk/artists/hamish-fulton/

Figure 3. John Wolseley at work a still from a NGV documentary showing artist John Wolseley (2015). The Sydney Morning Herald. Retrieved on 30 November 2016 from: http://www.smh.com.au/entertainment/art-and-design/artist-john-wolseley-on-adventurepainting-and-our-need-to-connect-with-the-earth-20150324-1 m464z.html

Figure 4. Joseph Mallord William Turner (1842), Snow storm- Steamboat off a harbour's mouth making signals in shallow water, and going by the lead. The Author was in this storm on the night Ariel left Harwich [Oil painting on canvas]. Tate Collection. Retrieved on 30 November 2016 from: http://www.tate.org.uk/art/artworks/turner-snow-storm-steam-boat-off-a-harbours-mouth$\underline{\mathrm{n} 00530}$

Figure 5. John Firth-Smith (1988). Through [Oil painting on linen]. In: G. Wilson, (1998). Escape artists: Modernists in the tropics. Cairns, Australia: Cairns Regional Gallery, p. 8.

Figure 6. Yvonne Cohen (1945). Mango trees [Oil painting on composition board]. In: G. Wilson (1998). Escape artists: Modernists in the tropics. Cairns, Australia: Cairns Regional Gallery, p. 23.

Figure 7. Jacqueline Scotcher (2012). Drivelines [Synthetic polymers \& ink on paper]. Courtesy of the artist. Retrieved on 30 November 2016 from: http://jacquelinescotcher.com/galleries/interiorexteriorl

Figure 8. Jacqueline Scotcher (2015). Wayfaring II [Synthetic polymers on canvas]. Courtesy of the artist. Retrieved on 30 November 2016 from: http://jacquelinescotcher.com/galleries/trilogy/

Figure 9. Jacqueline Scotcher (2016). Hinchinbrook Island Walk No. 1-4 [Synthetic polymers on canvas]. Photo by Jacqueline Scotcher, Courtesy of the artist.

Figure 10. Jacqueline Scotcher (2016). Hinchinbrook Island Walk No. 1 [Synthetic polymers on canvas]. Photo by Jacqueline Scotcher, Courtesy of the artist.

Figure 11. Jacqueline Scotcher (2015). Headspace [Synthetic polymers on canvas]. Courtesy of the artist. Retrieved on 1 December 2016 from: http://jacquelinescotcher.com/galleries/trilogy/

Figure 12: Jacqueline Scotcher (2015). Rock Hop [Synthetic polymers on canvas]. Courtesy of the artist. Retrieved on 1 December 2016 from: http://jacquelinescotcher.com/galleries/trilogy/ 